\title{
ECONOMIC VALUE ADDED IN FUNCTION OF DETERMINING INCENTIVE COMPENSATION SYSTEMS
}

\author{
Nemanja BERBER ${ }^{1}$, Milan PASULA ${ }^{2}$, Milan RADOŠEVIĆ ${ }^{2}$ \\ ${ }^{1}$ Higher School of Professional Business Studies, Novi Sad, Vladimira Perića - Valtera, 4, Republic of Serbia. E-mail: \\ berber_nemanja@yahoo.com \\ ${ }^{2}$ University of Novi Sad, Faculty of Technical Science, Novi Sad, Trg Dositeja Obradovića 6, Republic of Serbia
}

Accepted 10 December, 2012

\begin{abstract}
Corporate enterprises develop specific systems of rewarding managers for successful performances. By taking into account the need of creating shareholder value, it is necessary to implement method for measuring performance that would satisfy the objectives of shareholders and managers' interests. The optimal compensation model assumes that managers are motivated to create added value for shareholders. One method for modeling the reward system is economic value added (EVA). Economic value added represents a very attractive instrument for measuring corporate performances and its management. The subject of this paper was the analysis of the economic value added in function of creating incentive systems for managers, as well as the advantages and disadvantages of application of this method. Economic value added was presented as a concept that brings the objectivity in the system of modeling long-term incentives for managers and, thereby, reduces the risks associated with the incentive system.
\end{abstract}

Key words: human resource management, performance measurement, EVA, compensations, incentives.

\section{INTRODUCTION}

Modern business requires a high level of delegation of decision-making rights and responsibilities to managers. Capital owners are usually only interested in the value of company shares and the amount of dividends, while the organization and management of business activities and the achievement of corporate goals are delegated to the managerial structure of enterprise. In such circumstances, the question is how to reward and thus motivate managers to maximize their skills and abilities on the accomplishment of organizational goals.

Structuring acceptable compensation package for manager seeks to achieve the highest possible degree of concordance between shareholders and managers. Linking compensations for managers with actual managers' performances should focus managers on actions that would result in increasing shareholder value and realization of organizational goals. But in reality, the structure and amounts of the compensation packages often were not correlated with the level of managerial performances. Because of this, it is important to analyze some different performance measures that would be better base for structuring managerial rewards. As a possibility appears the concept of economic value added.

The subject of this paper was the analysis of the EVA in function of creating incentive systems for managers, as well as the advantages and disadvantages of application of this method. The aim was to present EVA as a concept that brings the objectivity in the system of modeling long-term incentives for managers and, thereby, reduces the risks associated with the incentive system.

\section{MAIN ISSUES IN THE CONCEPT OF INCENTIVE COMPENSATIONS FOR MANAGERS}

Especially interesting field of HRM is a system of compensation and benefits. Compensations are seen as a mechanism of development and intensification of the global corporate culture, the primary source of corporate control, which very explicitly associate achieved performance with the incurred costs and the link between all the sharper, sophisticated public discourses about central issues related to corporate governance in international contexts (Dowling et al., $2008,160)$ especially if we are talking about 
executive compensations. Compensations are direct financial costs for the organization, and if it is taken the fact that that labor costs may represent a great amount of total operating costs, there is the need of viewing the compensation system in terms of investments that will result in value added for the company. Also, incentive compensations are the most commonly used motivation factor for motivating managers to maximize their skills in the accomplishment of organizational goals.

At the beginning of analysis of manager's incentive compensation systems, it is important to pay attention to several questions that arise from this topic.

First is the agency problem in corporate governance. The managerial structure is responsible for the proposal, organization and implementation of business policies, while the functions of profit distribution and corporate control are left to the owners of capital. The primary task of managers is to ensure the continuous enlargement of a company shares. Since managers have their own goals and tasks, this often can lead to opportunistic behavior of managers in the sense that objectives of corporate enterprises are subordinated to the goals of managers. The situation when managers work harder to satisfy their own interests at the contrary of the goals of the owners is a called agency problem. The agency problem is most manifested when it comes to the determining compensation between shareholders and managers. Lack of sufficient information include weaker control of the managers by shareholders, but also opportunities for managers to increase the amount of their compensation to the system when there is no real basis.

Second question is related to the compensation systems and its components from the aspect of human resource management (HRM) theory. Compensations in contemporary HRM represent one of the most mentioned elements of this system, from the aspect of research, as well as the aspect of determining the best way to establish compensations. Authors of the expectation theory have suggested that motivation and performances are shaped based on the link between the effort and the reward and by the importance or valence of the reward to the person in question (Brewster et al., 2007, 121). Authors in HRM have established several models of compensation elements (̌̌tangl Šušnjar and Zimanji, 2005, 332; Dowling et al., 2008, 162; Briscoe et al., 2009, 245-252; Morley and Czarnecki, 2010, 12-14; Berber et al. 2012): base salary, allowances, awards, premia, overtime, incentives, bonus, commission, severance, perquisites, financial and retirement planning, health, pension, unemployment insurance, security services, loans and saving, outplacement, taxes and the like. It can be seen that some of those components are very useful instruments for motivation of employees and managers. According to The Wall Street Journal/Hay Group 2010 CEO Compensation Study (2011) the main components of the total compensation for managers are:

- base salary, according to Sigler (2011) it comprises $11.2 \%$ of executive compensation,

- $\quad$ annual incentives - bonuses,

- $\quad$ long term incentives - stock options grants, restricted stock grants, performance-based grants in equity and cash, restricted cash grants (which are not disclosed elsewhere),

- all other compensations - perquisites and personal benefits; tax gross-ups; discount stock purchases; company contributions to a definedcontribution plan; or company payment of insurance premiums.

- change in nonqualified deferred compensation earnings plus change in pension value - the aggregate change in the present value of accumulated defined-benefit and actuarial pension plans plus the above-market or preferential earnings on compensation that is deferred on a basis that is not tax-qualified.

The bonuses and long term incentives present the biggest part of managerial compensations, and because of that, it is important to determine the base on what managers should get these incentives.

Third issue related to the topic of compensations is the problems of rewarding managers. Main problems presented are the following:

- Cash bonuses tied to accounting numbers may motivate executives to manipulate the timing of revenues and expenses to maximize pay out to them.

- Rewarding top management with different forms of stock compensation may not tie the executive's efforts to company performance closely enough. The stock price may rise or fall from market forces and not from moves of the company's executives.

- Problems may also occur if the stock price declines after executive stock options are issued putting the options being way out of the money. With options so far out of the money, it may not give the manager the incentive to exert effort to move the stock price.

Executives may be enticed to manipulate accounting numbers when they are about to exercise their options to give the appearance of 
superior firm performance to drive up the stock price.

- Restricted stock rewards executives for performance but it restricts the stock from being sold by the executive for a period. This may not encourage the manager to set a high priority on accomplishing company goals in the near term (Sigler, 2011).

Beside presented compensation systems and problems, one of the most analyzed problems was the correlation of compensations with the performances of managers. So far many studies revealed that there is no strong correlation between these variables. For example, in the research of author Ozkan (2011), it have been pointed out to a weak effectiveness of corporate governance reports in the UK, which suggested that compensation for managers should be more closely linked with their performance. In one other research it was found that annual change in managerial compensation in the US during the 70 s and 80 s of the twentieth century to a large extent were not correlated with changes in corporate performances - the total compensation of managers have varied only $\$ 3$ to every $\$ 1,000$ change in shareholder wealth (Jensen and Murphy, 2010). Since managerial compensations are very complex category of HRM, there have to be made changes in modeling incentive compensations. One possible way to make performance - based incentive compensations is the concept of EVA.

\section{THE CONCEPT OF ECONOMIC VALUE ADDED}

The Economic Value Added is a management technique developed by the Stern Stewart \& Company consultant group (Stern et al., 1995). "EVA emphasizes the residual wealth creation in a company after all costs and expenses have been charged including the firm's cost of capital invested. In its simplest terms, EVA measures how much economic value in dollars; the company is creating, taking into account the cost of debt and equity capital" (Abdeen and Haight, 2002). EVA can be defined as the change in the NOPAT (Net Operating Profit after Taxes) minus the change in the Cost of the Capital used to generate this NOPAT (Rappaport, 1998; Kumar and Kaura, 2002). Thus, EVA depends basically on the firm operating profit, taxes, debt level, and the cost of capital. The calculation of EVA it can be proposed like (Rappaport, 1998; Tortella and Brusco, 2003):

$$
E V A=N O P A T-(D+E B V) \cdot(W A C C)
$$

where:
NOPAT

$\mathrm{D}$

EBV

WACC

Capital.

EVA calculation relies on generally accepted accounting principles to measure past management decisions. Because of that, a certain adjustments will have to be made in order to rectify any possible accounting distortions of income and investment. Examples of adjustments include research and development expenditures, and employee training costs that more correctly should be capitalized and amortized over their perceived years of future benefits (Abdeen and Haight, 2002). Besides this, it is also important to define the cost of capital, which is one of the most complex parts of EVA calculation. Usually, a capital asset pricing model (CAPM) is used. Under CAPM, cost of equity is given by the following formulation (Sharma and Kumar, 2010):

where:

$$
K e=R f+B i(R m-R f)
$$

Rf $\quad-$ Risk free return

$\mathrm{Rm} \quad$ - Expected market rate of return

$\mathrm{Bi}-$ Risk coefficient of particular investment

EVA is one of the measurements of the performances that present real economic state of the organization. It enables better protection of the shareholders interests since it measures the added value to the organization, in contrary to traditional performance measures like return on assets, equity or investments, earning per share and the like. But, there are some limitations with this concept. Namely, the main problem with EVA is the calculation of net operating income after tax and the average cost of capital. The fact that several adjustments have to be made in order to calculate economic income makes this performance metric complex. In some cases the number of adjustments may reach over one hundred and fifty (Abdeen and Haight, 2002). The complex calculation of EVA made author Ilić (2011) who for the first time showed calculation of EVA in the company business practices of Serbia. In favor of EVA speak the main proponents trough several principles:

- $\quad$ it helps in reducing agency conflict and improve decision making;

- $\quad$ it is more strongly associated with stock return than other measures;

- $\quad$ it improves stock performance;

- $\quad$ it adds more informational content in explaining stock returns; 
- $\quad$ EVA and market value are correlated (Sharma and Kumar, 2010).

There are also more contributions of this concept, and major of them are that management now pays greater attention to management of assets, allocation of resources, and capital structure including the operating leverage. EVA is appealing to developing companies that need to fund their projects through satisfying the value enhancement requirements of investors (Abdeen and Haight, 2002) and it is in function of value creation and enlargement for shareholders (Zakić et al., 2012; Ilić, 2011; Malinić, 2007; Balsey, 2005; Evans and Evans, 2002; Young and O'Byrne, 2001; Stern et al., 2001; Wallace, 1997). But one of the most important facts is that implementation of EVA into performance management system is that it can improve an incentive systems for managers. EVA can provide investors with a normal return on the company's shares-that is important not only for securities analysts in evaluating stocks, but also for corporate compensation committees in setting performance standards for management incentive compensation plans (O’Byrne, 1996).

\section{EVA IN FUNCTION OF INCENTIVE COMPENSATION SYSTEMS}

Some researches were made on the link between EVA and the form of executive compensation. An examination of the compensation structure and economic value added of 209 companies in 1995 1998 provided evidence supporting incentive compensation where EVA is found to be positively and significantly related to incentive based compensation (Evans and Evans, 2002). One comprehensive look at EVA based compensations gave authors Stern, Shiely and Ross (2001) who suggested a number of improvements over the original EVA bonus plan. Namely, EVA bonus plan measures excess EVA improvement as opposed to simply EVA growth over prior periods. It provides a more direct link to the true measure of shareholder wealth creation - returns above market expectations (Young and O'Byrne, 2001, p. 138). According these authors a following formula can be used to calculate a manager's bonus in each year (Young and O'Byrne, 2001, p. 139):

\section{CURRENT YEAR BONUS = TARGET BONUS + $y \%(\triangle E V A-E I)$

Target bonus is "the bonus earned by a manager for delivering the EVA improvement that is expected by investors (to be determined by the compensation committee prior to the performance period). This expected EVA improvement should be equivalent to the EVA that will provide shareholders with a cost of capital return on the market value of their investment in the business" (Balsley, 2005). If EVA is below this level bonuses will be reduced while returns of shareholders do not fall to zero. At this level there will be no bonuses for managers. If there is no return for the owners (negative EVA in the level of capital costs), there is no bonuses for management. Namely, creation of the return in the range from zero return to expected returns of shareholders provides bonuses from zero to the level of the target bonus. If EVA is sufficient to cover the expected returns of investors, then the managers realize the target bonus (Malinić, 2007).

$\triangle E V A$ - EI represents "the change in EVA less expected EVA improvement. This is meant to capture the incremental EVA that a manager has delivered above and beyond the EVA growth that investors expect and have already paid for. The percentage of the incremental performance (y \%) that is returned to management is established by the compensation committee" (Balsley, 2005).

Additional incentives beyond the level of the target bonus are provided for increasing the EVA above the level provided by covering the total cost of capital and only the part of EVA that is increased above the expected level. In this way it will be prevented the excessive increase of compensation costs. If the criteria for bonuses was any increase in EVA, then there will be situations in which one reached EVA (above the level that provides target bonus) is decreasing, which is usually accompanied by a decline in value of shares and managers will still exercise bonuses over target level (Malinić, 2007). Because of this, Stern Stewart \& Co proposed the use of a "bonus bank" designed to base a manager's annual bonus payout on multi-period EVA delivery. The mechanics of the bonus bank is presented as following:

- In every year, the "current year bonus" is calculated using the formula described above and based on the manager's performance during that year.

- That "current year bonus" is then placed in a "bonus bank" that also holds the deferred (or unpaid portion of) bonuses from prior years.

- $\quad$ The bonus bank balance (after the current year bonus has been included), rather than the current year bonus, then determines the amount of bonus actually earned by a manager each year. The amount earned is determined in two steps: 
- $\quad 100 \%$ of the bonus bank (if possible) is paid up to the amount of the target bonus, plus

- $\quad 1 / 3$ of the remaining bonus bank (after the target bonus) (Balsley, 2005).

The bank account concept with the vulnerable three - year payout gives the annual incentive compensation program a longer - term perspective and provides participants with ownership incentives as the account balances build or decline (Wallace, 1997).

\section{CONSLUSION}

Managerial compensations are very complex area of HRM. A mixture of compensations elements, importance of short and long - term incentives for managers and problem of rewarding in the past make this issue more sophisticated. Since the incentives are the most important part of executive compensation, those elements should be created in relation with the managerial performances. Usually, executive compensations was weakly correlated or even no correlated with the achieved performances. While values of shares were declining, managers were still exercising bonuses and other incentives. During past years because of the lack of sufficient information there have been weaker control of the managers by shareholders and managers were able to maximize their own interests in contrary to the interests of shareholders (agency problem). Because of the existence of all those issues and problems there is a need for improvement in the design of managerial compensations. One possibility, analyzed in this paper, was EVA.

EVA concept was understood as the contemporary technique for performance measurement. When it comes to the managerial compensations, EVA encourages managers to make decisions that are aligned with the creation of value for the shareholders. As it was described in the paper, EVA incentive compensations are based not only on the year increase in EVA, but on the increase that is above expected EVA improvement. Bonus bank is usually used to motivate managers to make decisions that will create superior performances and value for the shareholders continuously. This method will connect results of managers (EVA improvements) to the deferred bonus payout (payout will be set in defined time period, for example three years).

\section{REFERENCES}

The Wall Street Journal/Hay Group 2010 CEO Compensation Study. (2011, May, 21/02/2012).
Retrieved from

http://www.haygroup.com/downloads/ww/misc/ws j_2010_ceo_compensation_study_5-17-

11_web.pdf

Abdeen, A. M., \& Haight, T. G. (2002). A Fresh Look At Economic Value Added: Empirical Study Of The Fortune Five-Hundred Companies. The Journal of Applied Business Research, 18(2), 27-36.

Balsley, H. (Producer). (12/12/2005, 26/03/2012). Using

EVA to Align Management Incentives with

Shareholders' Interests. Retrieved from http://people.hbs.edu/mdesai/IFM05/HBalsley.pdf

Berber, N., Pasula, M., Radošević, M., Ikonov, D., \& Kočić Vugdelija, V. (2012). Internal Audit of Compensations and Benefits: Tasks and Risks in Production Systems. Engineering Economics, 23(4), 414-424.

Brewster, C., Sparrow, P., \& Vernon, G. (2007). International Human Resource Management (2nd ed.). London: Chartered Institute of Personnel and Development.

Briscoe, D. R., Schuler, R. S., \& Claus, L. (2009). International Human Resource ManagementPolicies and practice for multinational enterprises (3rd ed.). London and New York: Routledge.

Dowling, P. J., Festing, M., \& Engle, A. D., Sr. (2008). International Human Resource ManagementManaging people in a multinational context (5th ed.). London: Cengage Learning.

Evans, J., \& Evans, R. (2002). An Examination of Economic Value Added and Executive Compensation. Paper presented at the EFMA 2002 London Meeting. http://ssrn.com/abstract=313974

Ilić, M. (2011). Ekonomska dodata vrednost (EVA) kao savremeni koncept upravljanja performansama preduzeća. Ekonomski fakultet. Subotica.

Jensen, M. C., \& K.J., M. (2010). CEO incentives - It's not how much you pay, but how. Journal of Applied Corporate Finance, 22(1), 64-76.

Kumar, A. V., \& Kaura, M. N. (2002). Executive Compensations and Corporate Performance: An EVA Approach. South Asian Journal of Management, 9(3), 12-20.

Malinić, D. (2007). Kompenzacione šeme za menadžere Zbornik radova: Korporativno i javno upravljanje u funkciji razvoja konkurentnosti, Miločerski ekonomski forum. Beograd: Savez ekonomista Srbije.

Morley, L. C., \& Czarnecki, N. A. (2010). IPPF Guide: Auditing Executive Compensation and Benefits. Altamonte Springs, Fla., USA: The Institute of Internal Auditors.

O’Byrne, S. F. (1996). EVA and Market Value. Journal of Applied Corporate Finance, 9(1), 116-125.

Ozkan, N. (2011). CEO Compensation and Firm Performance: an Empirical Investigation of UK Panel Data. European Financial Management, 17(2), 260-285.

Rappaport, A. (1998). Creating Shareholders Value: A Guide for Managers and Investors. Englewood Cliffs: Prentice Hall.

Sharma, A. K., \& Kumar, S. (2010). Economic Value 
Added (EVA) - Literate Review and Relevant Issues. International Journal of Economics and Finance, 2(2), 200-220.

Sigler, K. J. (2011). CEO Compensation and Company Performance. Business and Economics Journal, 2011: BEJ-31, 1-8.

Štangl Šušnjar, G., \& Zimanji, V. (2005). Menadžment ljudskih resursa. Subotica: Ekonomski fakultet.

Stern, J. M., Shiely, J. S., \& Ross, I. (2001). The EVA Challenge: Implementing Value-Added Change in an Organization. New York: John Wiley \& Sons, Inc.

Stern, J. M., Stewart, G. B., \& Chew, D. H. (1995). The EVA Financial Management System. Journal of Applied Corporate Finance, 8(2), 32-46.
Tortella, D. B., \& Brusco, S. (2003). The Economic Value Added (EVA): an analysis of market reaction. Advances in Accounting, 20, 265-290.

Wallace, J. S. (1997). Adopting residual income-based compensation plans: Do you get what you pay for? . Journal of Accounting and Economics, 24, 275300.

Young, S. D., \& O'Byrne, S. F. (2001). EVA and ValueBased Management: A Practical Guide to Implementation. New York: McGraw Hill.

Zakić, V., Vunjak, N., Bešić, C., \& Simić, J. (2012). Significance of Economic Value Added in Shareholder Value Creation Process. Technics Technologies Education Management TTEM, 7(1), 180-185. 